\title{
STATUS OF SOLAR PV UTILIZATION FOR ENERGY SERVICES IN THE NIGERIAN HOUSING ESTATE
}

\author{
Olalekan Aquila Jesuleye, Adeyemi Oluwaseun Adepoju, Olutosin Foluso Arigbede \\ Department of Project Management Technology, School of Management Technology, Federal University of \\ Technology Akure, Km 7 Akure-Ilesa Expressway, Ondo State, Nigeria.
}

\begin{abstract}
This paper assessed the current status of Solar Photovoltaics (PV) and other energy sources for various household appliances in the Nigerian housing estates. A total of 292 questionnaires were administered to Solar PV users in the estates to elicit information on solar PV use. Model for Analysis of Energy Demand (MADE-II) was used to analyze the primary and other secondary data obtained for the study. The results showed that the current contribution of solar PV in energy demand split for the estates was still very low with a total share of $7.3 \%$ in spite of various government interventions. Its usage level constituted an insignificant share of $27.2 \%, 59.6 \%, 16.3 \%$, $0 \%, 0 \%, 0 \%, 0 \%$ and $6.9 \%$ for the total lighting, computing/internet, entertainment, process heat, cooking, refrigeration, water pumping and ventilation services requirement respectively.
\end{abstract}

Keywords-Alternative Means, Energy Supply, Renewable Energy, Solar Power, Sustainable Development

\section{INTRODUCTION}

A call to action was made in 2015 at the United Nations Summit for Sustainable Development for a much wider and greater access to affordable, reliable and sustainable energy as a prerequisite for eradicating poverty by 2030 [1]. World leaders reaffirm this in 2016 at their summit with a global consensus that: the Sustainable Development Goals (SDGs) is not achievable without efficient energy access to increase production, income, create jobs and reduce drudgery [2]. The importance of access to energy in facilitating economic development, reducing poverty, broadening the reach of education and improving health has been well explored $[3,4$, $5 \& 6]$.

Energy is one of the indispensable factors for continuous development and economic growth [7, 8 \& 9]. Energy poverty is a lack of access to modern energy services like lighting, space cooling, refrigeration, water pumping, etc. [10 \& 11]. Iwayemi [12] opines that there is an extreme electricity deficiency in Nigeria and the causes of these deficiencies are related to financial, socio-political, and structural issues that lead the power sector to record high energy losses from power generation, transmission, and distribution. Nigeria's current output of 4,420MW looks pretty hazardous compared to our projected demand of 26,561MW by 2020 [13].

According to Jesuleye [14], strategies for electrification must be renewable energy sources because Africa is extremely vulnerable to climate change and the continent has more solar radiation than any other continent on earth. The most pursue renewable energy source is solar photovoltaics (PV) because it is environmentally and weather friendly, low maintenance, possibility of expandability, it requires no fuel, it has no pollution, and it also has no noise. This system works by converting sunlight into electrical power. It is achieved by using a thin layer of semi-conducting material, normally silicon, concealed in a plastic casing or glass. They could have different sizes ranging from small versions used to power-on wristwatches to a system of hundreds of square meters of solar PV panels integrated to power small or large buildings. It is one of the cleanest forms of energy as it doesn't release emissions to the environment and its source is inexhaustible. The potential for electricity generation from solar energy is enormous.

According to the Renewable Energy Master plan (REMP) [15], Nigeria is positioned within a high sunshine belt and solar radiation is distributed fairly well within the country. Annual average of total solar radiation varies from about 12.6 $\mathrm{MJ} / \mathrm{m} 2$-day $(3.5 \mathrm{kWh} / \mathrm{m} 2$-day) in the coastal latitudes to about 25.2 MJ/ m2-day $(7.0 \mathrm{kWh} / \mathrm{m} 2$-day) in the far north. Resulting in an average annual solar energy intensity of $1934.5 \mathrm{kWh} / \mathrm{m} 2$-yr; thus an average of $6,372,613 \mathrm{PJ} /$ year $(\approx 1,770$ thousand $\mathrm{TWh} /$ year $)$ of solar energy falling on the whole land area of Nigeria annually.

The National Economic Empowerment and Development Strategy (NEEDS) which commenced in March 2004 sets an electrification target of providing $75 \%$ of the entire population with access to electricity by 2020 . The medium to long-term target for rural electrification set by the Federal Ministry of Power and steels in 2004 under the Rural Electrification Policy envisages that at least $10 \%$ of new users will be supplied with electricity using renewable energies. The Renewable Electricity Action Programme adopts that solar energy is required to supply approximately $18 \%$ of the electricity generated by renewable energies. 


\section{International Journal of Engineering Applied Sciences and Technology, 2020 Vol. 4, Issue 10, ISSN No. 2455-2143, Pages 386-394 \\ Published Online February 2020 in IJEAST (http://www.ijeast.com)}

Globally, the utilization of solar PV among residential is attracting more researchers' interests in recent times. Consequently, this research assesses the current status of Solar Photovoltaics (PV) utilization in the energy mix for energy services in Nigerian residential Estate.

The rest of the paper is organized as follows. Proposed embedding and extraction algorithms are explained in section II. Experimental results are presented in section III. Concluding remarks are given in section IV.

\section{LITERATURE REVIEW}

The status of solar Photovoltaic market is a rapidly growing worldwide [19]. During the period between 2000 and 2015 the growth rate of photovoltaic installations was of $41 \%$. It is observed that China and Taiwan since 2006 have been increasing the photovoltaic industry with strong growth rates. At the end of 2015 , its market share was about $71 \%$ of global sales. The market for photovoltaic systems will likely continue to grow in the future as strongly as so far, due to the thrust of subsidies, tax breaks and other financial incentives. Support for R \& D and photovoltaic technology change are crucial aspects in accelerating the widespread utilization of photovoltaic systems [19].

Europe contributed $40 \%$ of total cumulative PV installations in 2015 (in 2014 it was 48\%). European countries such as Germany, Denmark and Spain, in addition to Asian countries China and Taiwan, have used feed-in tariff (FIT) which is a political mechanism to encourage consumers to invest in renewable microgeneration. On the other hand, the United States, United Kingdom, Japan and Sweden, have used the RPS (Renewable Portfolio Standard), which is a regulation that requires that part of the energy consumed comes from renewable sources.

The facilities in China and Taiwan accounted for $21 \%$ of total cumulative installations (in 2014 was 17\%). In 2015, Germany accounted for about $16 \%(39.6 \mathrm{GWp})$ of cumulative installed PV capacity worldwide (242 GWp). In 2015, the newly installed capacity in Germany was about 1.4 GWP; in 2014 it was $1.9 \mathrm{GWp}$. In total, 1.5 million photovoltaic systems were installed in Germany.

Jesuleye (2017) [20] analyzed the current status of Solar Photovoltaics (PV) for lighting in Danjiwa and Dahuwa remote villages that are pilot sites for rural electrification projects in Nigeria. Model for Analysis of Energy Demand (MADE-II) was used to analyze the primary and other secondary data obtained for the study. The results showed that the current contribution of solar PV in the lighting demand split for the villages was still very low in spite of various government interventions. Its usage level constituted an insignificant share of $16.4 \%$ and $5.5 \%$ of the total lighting requirement for Danjiwa and Dahuwa villages respectively. For each village, lighting with incandescent bulbs was about $10 \%$ of this total requirement, while that of fluorescent lambs stood at $7 \%$ and 6.5 respectively. The research results also revealed that kerosene maintained a domineering share of $66 \%$ and $77 \%$ of the total demand in the two villages respectively.
Ismail, Ajide and Akingbesote (2012) [21], embarked on performance assessment of installed solar PV system in Oke agunla, Akure LG area of Ondo state in Nigeria, it was concluded that the PV systems were inefficient as a result of poor maintenance, lack of technical know-how and inability of the project contractors or managers to take these factors into consideration while embarking on the solar PV installations.

Melodi \& Famakin (2011) [22], in a study to determine the adequacy of solar electricity potential (SEP) for meeting the domestic demand of Akure, concluded that SEP in Akure is appreciable and sufficient as an alternative energy source for domestic needs.

\section{METHODOLOGY}

The methodology section contains the data and sample subsection which is followed by the description of measurements of variables and method of data analysis.

Adaptation of Model for Analysis of Demand for Energy (MADE-II) for Data Analysis

Model for Analysis of Demand Energy (with the acronyms MADE-II), developed at the Institute for Energy Economics and Rational use of Energy, University of Stuttgart, Germany in 1989, is the adapted energy demand analysis model for this paper. The Model combines the application of statistical, econometric and engineering process techniques as appropriate for the various sectors of the economy. As presented in Figure. 2 .

MADE-II is made up of 7 blocks of data in flow for demand analysis. Block 1 deals with general information about energy levels, base year and future time periods while information on development of population is presented in Block 2. Data analysis for useful energy demand in the households sector is treated in Block 3, while block 4 and 5 deal with the Households, Cottage Industries and Community Services sectors. The transport sector is not included in the analysis while block 7 deals with efficiencies, penetration factors and sectoral demand for Solar Electricity Lighting. Other Energy Services such as: Water Pumping for Drinking and Irrigation Purposes, Powering of TV, Video, Radio, Refrigeration, Ventilation, Cooking and Process Heat are not considered in the analysis due to dearth of data.

The basic analytical approach employed in MADE-II which makes it suitable for demand analysis of solar electricity in Nigeria is its flexibility and applicability for demand projection over short or long period. So also, analytical techniques adopted in MADE-II rest on the idea that energy is a means to an end and it is used together with other production factors to provide products (in form of goods and services) to the society. the basis of such considerations, the algorithm uses a different color image multiplied by the weighting coefficients of different ways to solve the visual distortion, and by embedding the watermark, wavelet coefficients of many ways, enhance the robustness of the watermark. 


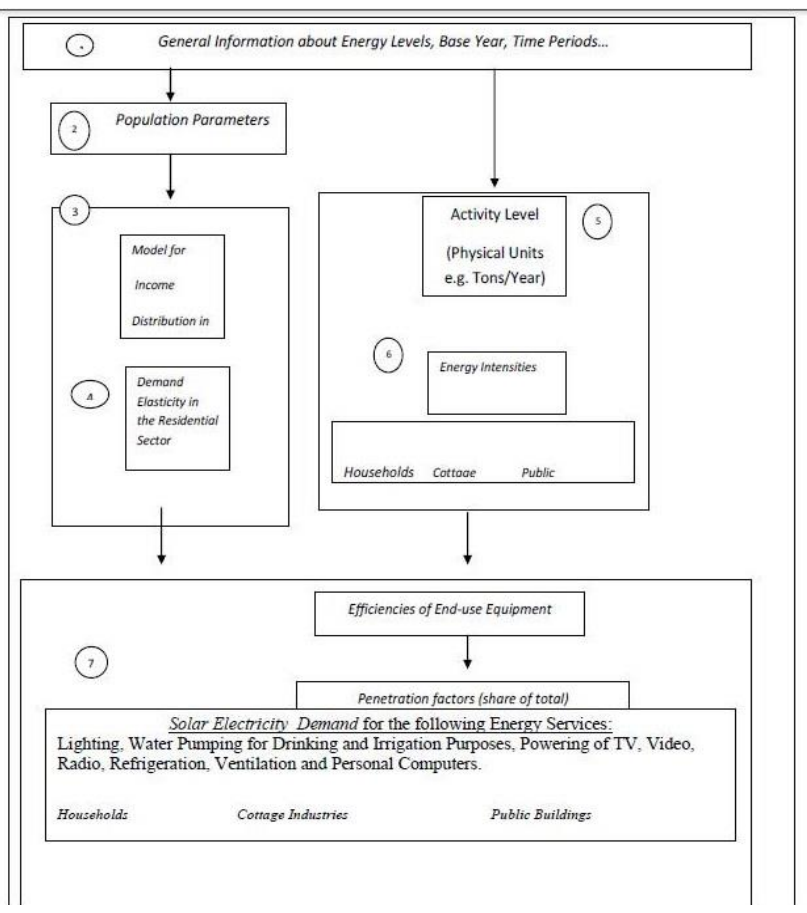

Fig. 1. Adapted Data Flow in MADE -II (Model for Analysis of Demand for Energy) (Jesuleye 2010)

Measurement of Variables for energy services by Solar PV in Each Estate

Energy consumption data of each estate in the study areas were used to quantify total demand for energy services. This involves the calculation of energy intensities as represented in the equation as below:

Energy Intensity $\left(\mathrm{EI}_{\mathrm{j}, \mathrm{t}}\right)=\frac{(\text { DSES } j, t) \text { Energy input }(W p)}{(A L j, t) \text { Population Share (Milion) }}$

Where,

$\operatorname{DSES}_{\mathrm{j} . \mathrm{t}}=\mathrm{AL}_{\mathrm{j}, \mathrm{t}} * \mathrm{EI}_{\mathrm{j}, \mathrm{t}}$

DSES $_{\mathrm{j}, \mathrm{t}}$ : Household demand D for Solar PV Services j (e.g. lighting ) in time t.

$\mathrm{AL}_{\mathrm{j}, \mathrm{t}}$ : Household Activity Level (AL) (Population share) for solar PV service $\mathrm{j}$ (e.g lighting) in time period t.

$\mathrm{EI}_{\mathrm{j}, \mathrm{t}}$ : Household Energy Intensity (EI) for Solar PV service j (e.g lighting) in time t.

Wp : Watt peak

Adapted from Jesuleye (2010)

General Information and Profiles of Solar PV Installations in the Study Areas.

Ijapo Housing Estate is located within the peripheral zone of the city near Oke Ijebu roundabout. It is a mixture of prototype-housing design and site-and-services. With a population of 3000, Table 1 shows a Profile of Solar PV installation in Ijapo. In Ijapo Housing Estate, the number of households Connected is 128, which makes $21.3 \%$ of the households. The most common application is solar home system installation and Solar Street light with a total capacity of $232 \mathrm{KW}$ which were installed between 2011 and 2019. The installation comprises of Solar Panel, Storage Battery, Inverter, Charge controllers and ELCB Breaker. The PV Installation is used as an alternative Energy source. The PV installations are Self-sponsored, and $58.6 \%$ of the respondents Stated that the PV system is working very well and last an average of 5-6 hours. The users are responsible for monitoring and sustainability.

Table 1 shows a summary/Profile of Solar PV installation in Ijapo Housing Estate.

\begin{tabular}{ccc}
\hline S/N & Characteristics & Remark \\
\hline 1 & Estimated populations & 3000 \\
\hline 2 & Average number of household & 600 \\
\hline 3 & Average number of people per & 5 \\
& household & 128 \\
\hline 4 & Number of household Connected & $21.3 \%$ \\
\hline 5 & Percentage of house connected & Solar Home system and solar \\
& Ttreet light \\
\hline 6 & Type of solar installation & $2011-2019$ \\
\hline 7 & Year of Installation of PV System & 232 kW \\
\hline 8 & Total capacity of PV installed & Solar Panel, Storage Battery, \\
& Major Component of PV & Inverter, Charge controllers, \\
& Installation & Alternative Energy source \\
\hline 10 & Objective of the PV Installation & Self-sponsored \\
\hline 11 & Sponsor of the PV installation & 58.6\% working very well \\
\hline 12 & Status of the installation & 6 \\
\hline 13 & Average hours of usage & User \\
\hline 14 & Monitoring and sustainability &
\end{tabular}

Alagbaka Housing Estate Extension is also located in the peripheral zone of the city near the Bishop's Court roundabout. It is a site-and-services estate where the residents purchased the land from the government in order to build by themselves while the government provides the services. With a population of 1540, Table 2 shows a Profile of Solar PV installation in the study area. In Alagbaka Housing Estate, the number of household Connected is 59, which makes $19.2 \%$ of the households Estate. The most common application is solar home system installation with a Total capacity of $93 \mathrm{~kW}$ which were installed between 2013 and 2018. The installation comprises of Solar Panel, Storage Battery, Inverter, Charge controllers and ELCB Breaker. The PV Installation is used as an alternative Energy source. The PV installations are Selfsponsored, and $54.2 \%$ of the respondents stated that the PV system is working very well and last an average of 5-6 hours. The users are responsible for monitoring and sustainability.

Table 2 shows a summary/Profile of Solar PV installation in Alagbaka Housing Estate

\begin{tabular}{ccc}
\hline $\mathbf{S} / \mathbf{N}$ & Characteristics & Remark \\
\hline 1 & Estimated populations & 1540 \\
\hline 2 & Average number of household & 308 \\
\hline 3 & $\begin{array}{c}\text { Average number of people per } \\
\text { household }\end{array}$ & 5 \\
\hline 4 & Number of household Connected & 59 \\
\hline
\end{tabular}




\begin{tabular}{ccc}
\hline 5 & Percentage of house connected & $19.2 \%$ \\
\hline 6 & Type of solar installation & Solar Home system \\
\hline 7 & Year of Installation of PV System & $2013-2018$ \\
\hline 8 & Total capacity of PV installed & $93 \mathrm{~kW}$ \\
\hline 9 & $\begin{array}{c}\text { Major Component of PV } \\
\text { Installation }\end{array}$ & $\begin{array}{c}\text { Solar Panel, Storage Battery, } \\
\text { Inverter, Charge controllers, } \\
\text { ELCB Breaker }\end{array}$ \\
\hline 10 & Objective of the PV Installation & Alternative Energy source \\
\hline 11 & Sponsor of the PV installation & Self-sponsored \\
\hline 12 & Status of the installation & $54.2 \%$ working very well \\
\hline 13 & Average hours of usage & 6 \\
\hline 14 & Monitoring and sustainability & User \\
\hline
\end{tabular}

Sunshine Gardens Housing Estate is located in a suburb of the Akure city called Oba-Ile. It is a prototype-housing estate built through Public-Private Partnership between the State government and a private developer, who built all the houses and provided the services, while the users purchased the already finished houses. With a population of 880 , Table 3 presents a Profile of Solar PV installation in the study area. In Sunshine Gate Housing Estate, the number of household Connected is 32 , which makes $18.2 \%$ of the households in the Estate. The most common application is solar home system installation with a Total capacity of $39.5 \mathrm{~kW}$ which were installed between 2012 and 2018. The installation comprises of Solar Panel, Storage Battery, Inverter, Charge controllers and ELCB Breaker. The PV Installation is used as an alternative Energy source. The PV installations are Selfsponsored, and $87.5 \%$ of the respondents Stated that the PV system is working very well and last an average of 5-6 hours. The users are responsible for monitoring and sustainability.

Table 3 shows a summary/Profile of Solar PV installation in Sunshine Housing Estate

\begin{tabular}{ccc}
\hline S/N & Characteristics & Remark \\
\hline 1 & Estimated populations & 880 \\
\hline 2 & Average number of household & 176 \\
\hline 3 & $\begin{array}{c}\text { Average number of people per } \\
\text { household }\end{array}$ & 5 \\
& Number of household Connected & 32 \\
\hline 4 & Percentage of house connected & $18.2 \%$ \\
\hline 5 & Type of solar installation & Solar Home system \\
\hline 6 & Year of Installation of PV System & $2012-2018$ \\
\hline 7 & Total capacity of PV installed & $39.5 \mathrm{~kW}$ \\
\hline 8 & Major Component of PV & $\begin{array}{c}\text { Solar Panel, Storage Battery, } \\
\text { Inverter, Charge controllers, }\end{array}$ \\
\hline & & ELCB Breaker \\
\hline 10 & Objective of the PV Installation & Alternative Energy source \\
\hline 11 & Sponsor of the PV installation & Self-sponsored \\
\hline 12 & Status of the installation & $87.5 \%$ working very well \\
\hline 13 & Average hours of usage & 6 \\
\hline 14 & Monitoring and sustainability & User \\
\hline
\end{tabular}

Data and Sample Population

The population for this study comprises of Solar PV users in the three housing estates under study namely: Ijapo (IHE), Alagbaka Extension (AHEE) and Sunshine Gardens Housing Estates (SGHE). The number of housing units in IHE is 600, while for AHEE and SGHE are 308 and 176 respectively. This brings the total housing units for the study area to 1,084 buildings [27].
The sample size for solar PV users using Using Yamane formula is;

$$
\begin{aligned}
& \mathrm{n}=\frac{N}{1+N(e) 2} \\
& =\frac{1084}{1+1084(0.0025)}
\end{aligned}
$$$$
=292 \text { respondents }
$$

Using the bourleys formula this translates to sample sizes of 162, 83 and 47 for IHE, AHEE and SGHE respectively.

Sample size for Ijapo Estate $=\frac{600 \times 292}{1084}=162$ respondents

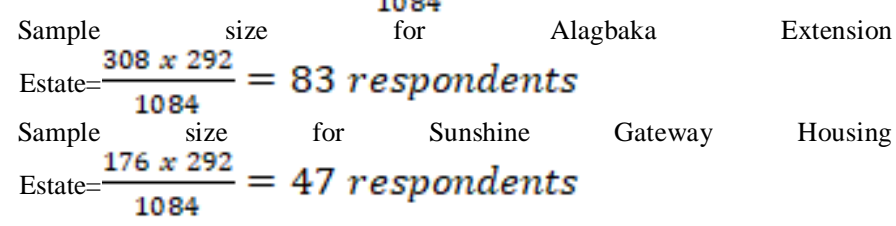

\section{RESULTS AND THE ANALYSES}

This section presents the obtained background information of the household in the estates, and status of solar PV utilization. The response rate of the survey questionnaire collected was examined in line with the study of Cooper and Schindler (2006) [23], who explained that the collected raw data should be examined for correctness, accuracy and completeness. In this study, 300 copies of questionnaire were administered to respondents. 165 questionnaires were administered in Ijapo Housing Estate, and 128 were completed correctly and returned, representing a percentage response of $78 \%$. 85 was distributed in Alagbaka Housing Estate, and 59 were completed correctly and returned representing a percentage response of $69 \%$ while 50 was shared in Sunshine Housing Estate, and 32 were completed correctly and returned representing a percentage response of $64 \%$. A total of 219 were completed correctly and returned, representing a percentage response of $73 \%$, as shown in Table 2. Mugenda and Mugenda (2003) [24], states that a response rate of 50\% is adequate for analysis and reporting; a rate of $60 \%$ is good, and a response rate of $70 \%$ and over is Excellent. Hence the response rate was satisfactory, as indicated in Table 2.

Table 2: Response Rate of Questionnaires Distributed and Retrieved

\begin{tabular}{lllll}
\hline Questionnaires & IHE & AHE & SHE & Total \\
\hline $\begin{array}{l}\text { Number Distributed } \\
\begin{array}{l}\text { Number Received and } \\
\text { used }\end{array}\end{array}$ & 165 & 85 & 50 & 300 \\
Percentage & 128 & 59 & 32 & 219 \\
\hline
\end{tabular}

\section{Descriptive analysis}

Demographic information of the households was gathered. First, the researcher sought to establish the gender of the respondents. Their responses are shown in Table 2. In Ijapo Housing Estate (IHE), 84.4\% of the respondents are males, while $15.6 \%$ are female. In Alagbaka Housing Estate (AHE), $81.4 \%$ of the respondents are males, while $18.6 \%$ are female. In Sunshine Housing Estate (SHE), all the respondents are males. Overall $85.8 \%$ of the household heads were males while as $14.2 \%$ of the household heads were females. This implies that there were more male respondents than females. This may be so because of the dominance of male as head of 
household in Africa [25]. This, however, will not affect the responses from the respondents, thereby creating any form of biasness. Next, sought to establish the age of the household heads. Their responses are highlighted in Table 2. In Ijapo Housing Estate (IHE), None $(0 \%)$ of the respondents were aged below 20 years, $10.9 \%$ of the household heads were aged between 21 to 29 years, $48.4 \%$ of the household heads were aged between 31 to 39 years and $40.6 \%$ of the household heads were aged 40 years and above. In Alagbaka Housing Estate (AHE), None $(0 \%)$ of the respondents were aged below 20 years, and between 21 to 29 years, $76.3 \%$ of the household heads were aged between 31 to 39 years, and $23.7 \%$ of the household heads were aged 40 years and above. In Sunshine Housing Estate (SHE), None $(0 \%)$ of the respondents were aged below 20 years, and between 21 to 29 years, $57.5 \%$ of the household heads were aged between 31 to 39 years, and $36.1 \%$ of the household heads were aged 40 years and above. Overall None $(0 \%)$ of the respondents were aged below 20 years, $6.4 \%$ of the household heads were aged between 21 to 29 years, $57.5 \%$ of the household heads were aged between 31 to 39 years, and $36.1 \%$ of the household heads were aged 40 years and above. This shows that the largest population of respondents were young and matured enough; as a result, they were able to understand issues related to solar technology. Table 2 also reflect a compliment to their level of education as the study composition indicates clearly that in Ijapo Housing Estate (IHE), $71.1 \%$

Table 2: Demographic Information of Respondents

\begin{tabular}{lcccccccc}
\hline Characteristics & IHE & \% & AHE & \% & SHE & \% & Total & Percentager \\
\hline Gender & & & & & & & & \\
Male & 108 & 84.4 & 48 & 81.4 & 32 & 100 & 188 & 85.8 \\
Female & 28 & 15.6 & 11 & 18.6 & 0 & 0 & 31 & 14.2 \\
Total & $\mathbf{1 2 8}$ & $\mathbf{1 0 0}$ & $\mathbf{5 9}$ & $\mathbf{1 0 0}$ & $\mathbf{3 2}$ & $\mathbf{1 0 0}$ & $\mathbf{2 1 9}$ & $\mathbf{1 0 0 . 0}$ \\
Age Group & & & & & & & & \\
(Years) & & & & & & & & \\
Below 20 & 0 & 0 & 0 & 0 & 0 & 0 & 0 & 0 \\
$21-29$ & 14 & 10.9 & 0 & 0 & 0 & 0 & 14 & 6.4 \\
$30-39$ & 62 & 48.4 & 45 & 76.3 & 19 & 59.4 & 126 & 57.5 \\
40 and Above & 52 & 40.6 & 14 & 23.7 & 13 & 40.6 & 79 & 36.1 \\
Total & $\mathbf{1 2 8}$ & $\mathbf{1 0 0}$ & $\mathbf{5 9}$ & $\mathbf{1 0 0}$ & $\mathbf{3 2}$ & $\mathbf{1 0 0}$ & $\mathbf{2 1 9}$ & $\mathbf{1 0 0 . 0}$ \\
Respondent's & & & & & & & & \\
Educational & & & & & & & & \\
Qualification & & & & & & & & \\
OND/Certificates & 0 & 0 & 0 & 0 & 0 & 0 & 0 & 0 \\
HND & 8 & 6.3 & 3 & 5.1 & 1 & 3.1 & 12 & 5.5 \\
BTech/BSc & 91 & 71.1 & 51 & 86.4 & 23 & 71.9 & 165 & 75.3 \\
Masters & 28 & 21.9 & 5 & 8.5 & 8 & 25.0 & 41 & 18.7 \\
PhD & 1 & 0.8 & 0 & 0 & 0 & 0 & 1 & .5 \\
Total & $\mathbf{1 2 8}$ & $\mathbf{1 0 0}$ & $\mathbf{5 9}$ & $\mathbf{1 0 0}$ & $\mathbf{3 2}$ & $\mathbf{1 0 0}$ & $\mathbf{2 1 9}$ & $\mathbf{1 0 0 . 0}$ \\
\hline
\end{tabular}

of the respondents have already earned a bachelor degree, while $6.3 \%, 21.9 \%$ and $0.8 \%$ are holders of HND, Masters and $\mathrm{PhD}$ Respectively. In Alagbaka Housing Estate (AHE), 86.4\% of the respondents have already earned a bachelor degree, while $5.1 \%$ and $8.5 \%$ are holders of HND, Masters Respectively and none $(0 \%)$ are OND/Certificate and $\mathrm{PhD}$ holder. In Sunshine Housing Estate (SHE), 71.9.4\% of the respondents have already earned a bachelor degree, while $3.1 \%$ and $25 \%$ are holders of HND, Masters Respectively and none $(0 \%)$ are OND/Certificate and $\mathrm{PhD}$ holder. Overall, $75.3 \%$ of the respondents have already earned a bachelor degree, while $5.5 \%, 18.7 \%$ and $0.5 \%$ are holders of HND, Masters and PhD Respectively. This might be an implication that they are well informed, and possessed the ability to assess and process information (tangible and intangible benefit accrue to the use of Solar PV) toward making a decision in line with the utilization of a Solar PV.

Next, socio-economic information of the respondents was gathered. First, the researcher sought to establish the Family structure of the households. Their responses are highlighted in Table 3. In Ijapo Housing Estate (IHE), $75.8 \%$ of the respondents are married with dependents, $13.3 \%$ are single with no dependent, $7.8 \%$ are single with dependents, and $3.1 \%$ are married with no dependent. In Alagbaka Housing Estate (AHE), $94.9 \%$ of the respondents are married with dependents, $3.4 \%$ are single with dependents, $1.7 \%$ are married with no dependent, and none $(0 \%)$ are single with no dependent. In Sunshine Housing Estate (SHE), 93.7\% of the respondents are married with dependents, $6.3 \%$ are married with no dependent, and none $(0 \%)$ are single with dependents and single with no dependent. Overall, $83.6 \%$ of the respondents are married with dependents, $3.2 \%$ are married with no dependent, $7.8 \%$ are single with no dependents, and $5.5 \%$ are single with dependents. This shows that the largest population of the respondent have high energy demand. Table 3 further reveals the number of people per household. The result shows that in Ijapo Housing Estate (IHE), 77.3\% of the gespondents have $2-5$ people living in their house. $11.7 \%$ have $6-9$ people living in their house, $0.8 \%$ have above 9 5.8 people living in their house, and $10.2 \%$ are staying alone. In 4.2 Alagbaka Housing Estate (AHE), 93.2\% of the respondents 00.0 have $2-5$ people living in their house. $6.8 \%$ have $6-9$ people living in their house, none $(0 \%)$ are staying alone and have above 9 people living in their house. In Sunshine Housing Estate (SHE), $96.9 \%$ of the respondents have $2-5$ people living in their house. $3.1 \%$ have $6-9$ people living in their 5 house, none $(0 \%)$ are staying alone and have above 9 people 6.1 living in their house. Overall, majority $(84.5 \%)$ of the 00.0 respondents have $2-5$ people living in their house. $9.1 \%$ have $6-9$ people living in their house, $0.5 \%$ have above 9 people living in their house and $5.9 \%$ are staying alone. This align with the work of Olaniyan, McLellan, Ogata and Tezuka,

02018 [26] that in the urban areas there are fewer people per 5.5 household. Table 3 also shows the income distribution of the 5.3 household. The result also shows that in Ijapo Housing Estate 7 (IHE), 48.4\% of the respondents earns \#100,000 - \#250,000 per month, 32\% earns \#250,000 - \#500,000 monthly, 11\% 100.0 earns Below \#100,000, 6.3\% earns \#500,000 - \#1,000,000 and Table 3: Socio-economic Information of the respondents

\begin{tabular}{|c|c|c|c|c|c|c|c|c|}
\hline Characteristics & IHE & $\%$ & AHE & $\%$ & SHE & $\%$ & TOTAL & $\%$ \\
\hline \multicolumn{9}{|l|}{ Family } \\
\hline $\begin{array}{l}\text { Single (no } \\
\text { dependent) }\end{array}$ & 17 & 13.3 & 0 & 0 & 0 & 0 & 17 & 7.8 \\
\hline $\begin{array}{l}\text { Single (with } \\
\text { dependents) }\end{array}$ & 10 & 7.8 & 2 & 3.4 & 0 & 0 & 12 & 5.5 \\
\hline $\begin{array}{l}\text { Married (no } \\
\text { dependent) }\end{array}$ & 4 & 3.1 & 1 & 1.7 & 2 & 6.3 & 7 & 3.2 \\
\hline $\begin{array}{l}\text { Married (with } \\
\text { Dependents) }\end{array}$ & 97 & 75.8 & 56 & 94.9 & 30 & 93.7 & 183 & 83.6 \\
\hline Total & 128 & 100 & 59 & 100 & 32 & 100 & 219 & 100.0 \\
\hline
\end{tabular}




\begin{tabular}{|c|c|c|c|c|c|c|c|c|}
\hline \multicolumn{9}{|l|}{$\begin{array}{l}\text { Number of } \\
\text { People per } \\
\text { household }\end{array}$} \\
\hline $2-5$ & 99 & 77.3 & 55 & 93.2 & 31 & 96.9 & 185 & 84.5 \\
\hline $6-9$ & 15 & 11.7 & 4 & 6.8 & 1 & 3.1 & 20 & 9.1 \\
\hline above 9 & 1 & 0.8 & 0 & 0 & 0 & 0 & 1 & .5 \\
\hline Total & 128 & 100 & 59 & 100 & 32 & 100 & 219 & 100.0 \\
\hline \multicolumn{9}{|l|}{$\begin{array}{l}\text { Monthly } \\
\text { Income }\end{array}$} \\
\hline $\begin{array}{l}\text { Below } \\
\# 100,000\end{array}$ & 15 & 11.7 & 0 & 0 & 0 & 0 & 15 & 6.8 \\
\hline $\begin{array}{l}\# 100,000- \\
\# 250,000\end{array}$ & 62 & 48.4 & 48 & 81.4 & 22 & 68.8 & 132 & 60.3 \\
\hline $\begin{array}{l}\# 250,000- \\
500,000\end{array}$ & 41 & 32.0 & 8 & 13.6 & 10 & 31.2 & 59 & 26.9 \\
\hline $\begin{array}{l}\# 500,000- \\
\# 1,000,000\end{array}$ & 8 & 6.3 & 3 & 5.1 & 0 & 0 & 11 & 5.0 \\
\hline $\begin{array}{l}\text { above } \\
\# 1,000,000\end{array}$ & 2 & 1.6 & 0 & 0 & 0 & 0 & 2 & .9 \\
\hline Total & 128 & 100 & 59 & 100 & 32 & 100 & 219 & 100.0 \\
\hline \multicolumn{9}{|l|}{$\begin{array}{l}\text { Average } \\
\text { Monthly } \\
\text { electricity Bill }\end{array}$} \\
\hline $\begin{array}{l}\# 5000- \\
\# 10,000\end{array}$ & 35 & 27.3 & 40 & 67.8 & 20 & 62.5 & 95 & 43.4 \\
\hline $\begin{array}{l}\# 10,000- \\
\# 15,000\end{array}$ & 45 & 35.2 & 14 & 23.7 & 2 & 6.3 & 61 & 27.9 \\
\hline $\begin{array}{l}\# 15,000- \\
20,000\end{array}$ & 25 & 19.5 & 3 & 5.1 & 0 & 0 & 28 & 12.8 \\
\hline above $\# 20,000$ & 0.8 & 6.3 & 2 & 3.4 & 0 & 0 & 10 & 4.6 \\
\hline Total & 128 & 100 & 59 & 100 & 32 & 100 & 219 & 100.0 \\
\hline
\end{tabular}

$1.6 \%$ earns above \#1,000,000 per month. In Alagbaka Housing Estate (AHE), $81.4 \%$ of the respondents earns $\# 100,000$ - \#250,000 per month, $13.6 \%$ earns \#250,000 \#500,000 monthly, 5.1\% earns \#500,000 - \#1,000,000 and none $(0 \%)$ earns Below \#100,000, and above \#1,000,000 per month. In Sunshine Housing Estate (SHE), $68.8 \%$ of the respondents earns $\# 100,000$ - \#250,000 per month, 31.2\% earns \#250,000 - \#500,000 monthly, and none (0\%) earns below \#100,000, between\#500,000 - \#1,000,000, and above $\# 1,000,000$ per month. Overall, $60.3 \%$ of the respondents earns \#100,000 - \#250,000 per month, 26.9\% earns \#250,000 \#500,000 monthly, 6.8\% earns Below \#100,000, 5\% earns $\# 500,000$ - \#1,000,000 and 0.9\% earns above \#1,000,000 per month. Table 3 further reveals that in Ijapo Housing Estate (IHE), $27.3 \%$ pay \#5,000 - \#10,000 for electricity bill per month. $35.2 \%$ pay \#10,000 - \#15,000, $19.5 \%$ pay \#15,000 $\# 20,000,6.3 \%$ pay above \#20,000 and $11.7 \%$ pay below \#5,000 for electricity bill per month. In Alagbaka Housing Estate (AHE), 67.8\% pay \#5,000 - \#10,000 for electricity bill per month. $23.7 \%$ pay \#10,000 - \#15,000, 5.1\% pay \#15,000 $\# 20,000$, and $3.4 \%$ pay above \#20,000 and none $(0 \%)$ pay below \#5,000 for electricity bill per month. In Sunshine Housing Estate (SHE), 62.5\% pay \#5,000 - \#10,000 for electricity bill per month. $6.3 \%$ pay \#10,000 - \#15,000, 31.2\% pay below \#5,000 and none $(0 \%)$ pay \#15,000 - \#20,000 and above \#20,000 for electricity bill per month. Overall, $43.4 \%$ pay \#5,000 - \#10,000 for electricity bill per month. $27.9 \%$ pay $\# 10,000$ - \#15,000, 12.8\% pay \#15,000 - \#20,000, $4.6 \%$ pay above \#20,000 and $11.4 \%$ pay below \#5,000 for electricity bill per month.
Status of Solar PV utilization for energy services in the study area

As shown in Table 4, in Ijapo Housing Estate (IHE), 80.5\% have their energy source to be Grid supply + Generator + Solar PV. 9.4\% use Grid + Solar PV, 2.3 use Grid supply + generator, 3.9 use Grid Supply only, 2.3 use generator only, and $2.4 \%$ use Solar PV only to power their Household. In Alagbaka Housing Estate (AHE), 96.6\% have their energy source to be Grid supply + Generator + Solar PV. $1.7 \%$ use Grid + Solar PV, 1.7 use Grid supply + generator, none $(0 \%)$ use Grid Supply only, Generator only, and use Solar PV only to power their Household. In Sunshine Housing Estate (SHE), 93.8\% have their energy source to be Grid supply + Generator + Solar PV. 3.1\% use Grid + Solar PV, 3.1 use Grid supply + generator, none $(0 \%)$ use Grid Supply only, Generator only, and use Solar PV only to power their Household. Overall, $86.8 \%$ have their energy source to be Grid supply + Generator + Solar PV. 6.4\% use Grid + Solar PV, 2.3 use Grid supply only, 0.5 use generator only, 2.3 use Grid supply + Generator, and $1.4 \%$ use Solar PV only to power their Household. This implies that majority of the respondent have a combination of various alternative energy source including Solar PV, petrol, diesel, and gas powered generators. Also, in Ijapo Housing Estate (IHE), 96.9\% installed solar home system while 3.1\% of the respondent installed Solar Street light. In Alagbaka Housing Estate (AHE) and Sunshine Housing Estate (SHE), all $(100 \%)$ their installation is Solar Home System. Overall, $98.2 \%$ installed solar home system while $1.8 \%$ of the respondent installed Solar Street light. This implies that majority of the respondents use solar PV as an alternative energy source. Table 4 also shows that in Ijapo Housing Estate (IHE), 30.5\% installed the PV system in 2016, 27.3\% installed the PV system in $2017,18 \%$ of the installation was in 2018 , $11.7 \%$ in $2015,3.9 \%$ in $2014,3.1 \%$ in $2019,3.1 \%$ in 2012 , $1.6 \%$ in 2013 and 0.8 in 2011. In Alagbaka Housing Estate (AHE), 22.0\% installed the PV system in 2016, 23.7\% installed the PV system in 2017, $20.3 \%$ of the installation was in $2014,16.9 \%$ in $2018,13.6 \%$ in $2013,3.4 \%$ in 2015 , and none $(0 \%)$ in 2011, 2012, and 2019. In Sunshine Housing Estate (SHE), 28.1\% installed the PV system in 2015, 25.0\% installed the PV system in 2016, $18.8 \%$ of the installation was in $2014,9.4 \%$ in $2017,6.3 \%$ in 2012, 2013 and 2018, and none $(0 \%)$ in 2011 and 2019. Overall, 2016 is the year with the highest amount of Solar PV installation as $27.4 \%$ of the respondent installed their $\mathrm{PV}$ in 2016. $0.5 \%, 2.7 \%, 5.5 \%$, $10.5 \%, 11.9 \%, 23.7 \%, 16.0 \%$ and $1.8 \%$ installed their PV system in 2011, 2012, 2013, 2014, 2015, 2017, 2018 and 2019 respectively. This might be as a result of the call to action that was made in 2015, also known as a sustainable development goal. Precisely, goal 7- ensure access to affordable, sustainable, modern energy for all and goal 13- Take urgent action to combat climate change and its impacts (UNCA, 2019). Table 3 further reveals that in Ijapo Housing Estate (IHE), $52.3 \%$ of the Respondents installed a $1.5 \mathrm{~kW} \mathrm{PV}$ system, $14.1 \%$ installed a $1 \mathrm{~kW}$ PV system, $11.7 \%$ installed a $2 \mathrm{~kW}$ PV system, $13.3 \%$ installed a $2.5 \mathrm{~kW}$ PV system, $4.7 \%$ installed a $3.5 \mathrm{~kW}$ PV system, $2.3 \%$ installed a $4 \mathrm{~kW}$ PV system, and $0.8 \%$ installed a $3 \mathrm{~kW}$ and $5 \mathrm{~kW}$ PV system. This shows that the total capacity of PV installed is $232 \mathrm{~kW}$. 
Table 4: Status of Solar PV utilization for energy services in $\quad 3.5$ the study area

\begin{tabular}{|c|c|c|c|c|c|c|c|c|}
\hline Characteristics & IHE & $\%$ & AHE & $\%$ & SHE & $\%$ & Total & $\%$ \\
\hline \multicolumn{9}{|l|}{$\begin{array}{l}\text { Energy } \\
\text { sources }\end{array}$} \\
\hline $\begin{array}{l}\text { Grid Supply } \\
\text { Only }\end{array}$ & 5 & 3.9 & 0 & 0 & 0 & 0 & 5 & 2.3 \\
\hline Solar PV only & 3 & 2.3 & 0 & 0 & 0 & 0 & 3 & 1.4 \\
\hline Generator only & 1 & .8 & 0 & 0 & 0 & 0 & 1 & .5 \\
\hline $\begin{array}{l}\text { Grid Supply + } \\
\text { Generator }\end{array}$ & 3 & 2.3 & 1 & 1.7 & 1 & 3.1 & 5 & 2.3 \\
\hline $\begin{array}{l}\text { Grid Supply + } \\
\text { Generator + } \\
\text { Solar PV }\end{array}$ & 103 & 80.5 & 57 & 96.6 & 30 & 93.8 & 190 & 86.8 \\
\hline $\begin{array}{l}\text { Grid Supply + } \\
\text { Solar PV }\end{array}$ & 12 & 9.4 & 1 & 1.7 & 1 & 3.1 & 14 & 6.4 \\
\hline Total & 128 & 100.0 & 59 & 100.0 & 32 & 100.0 & 219 & 100.0 \\
\hline \multicolumn{9}{|l|}{$\begin{array}{l}\text { Type of solar } \\
\text { PV installed }\end{array}$} \\
\hline $\begin{array}{l}\text { Solar Home } \\
\text { System }\end{array}$ & 124 & 96.9 & 59 & 100.0 & 32 & 100.0 & 215 & 98.2 \\
\hline $\begin{array}{l}\text { Solar Street } \\
\text { Lighting }\end{array}$ & 4 & 3.1 & 0 & 0 & 0 & 0 & 4 & 1.8 \\
\hline Total & 128 & 100.0 & 59 & 100.0 & 32 & 100.0 & 219 & 100.0 \\
\hline \multicolumn{9}{|l|}{$\begin{array}{l}\text { Year of } \\
\text { installation of } \\
\text { PV system }\end{array}$} \\
\hline 2011 & 1 & .8 & 0 & 0 & 0 & 0 & 1 & .5 \\
\hline 2012 & 4 & 3.1 & 0 & 0 & 2 & 6.3 & 6 & 2.7 \\
\hline 2013 & 2 & 1.6 & 8 & 13.6 & 2 & 6.3 & 12 & 5.5 \\
\hline 2014 & 5 & 3.9 & 12 & 20.3 & 6 & 18.8 & 23 & 10.5 \\
\hline 2015 & 15 & 11.7 & 2 & 3.4 & 9 & 28.1 & 26 & 11.9 \\
\hline 2016 & 39 & 30.5 & 13 & 22.0 & 8 & 25.0 & 60 & 27.4 \\
\hline 2017 & 35 & 27.3 & 14 & 23.7 & 3 & 9.4 & 52 & 23.7 \\
\hline 2018 & 35 & 18.0 & 10 & 16.9 & 2 & 6.3 & 35 & 16.0 \\
\hline 2019 & 4 & 3.1 & 0 & 0 & 0 & 0 & 4 & 1.8 \\
\hline Total & 128 & 100.0 & 59 & 100.0 & 32 & 100.0 & 219 & 100.0 \\
\hline
\end{tabular}

In Alagbaka Housing Estate (AHE), $47.5 \%$ of the Respondents installed a $1.5 \mathrm{~kW}$ PV system, $30.5 \%$ installed a $1 \mathrm{~kW}$ PV system, $11.9 \%$ installed a $2 \mathrm{~kW}$ PV system, 3.4\% installed a $2.5 \mathrm{~kW}$ PV system, $6.8 \%$ installed a $3.5 \mathrm{~kW}$ PV system, and $0 \%$ installed a $3 \mathrm{~kW}, 4 \mathrm{~kW}$ and $5 \mathrm{~kW}$ PV system. This shows that the total capacity of PV installed is $93 \mathrm{~kW}$. In Sunshine Housing Estate (SHE), $46.9 \%$ of the Respondents installed a $1.5 \mathrm{~kW}$ PV system, $53.1 \%$ installed a $1 \mathrm{~kW}$ PV system, and $0 \%$ installed a $2 \mathrm{~kW}, 2.5 \mathrm{~kW}, 3 \mathrm{~kW}, 3.5 \mathrm{~kW}, 4 \mathrm{~kW}$ and $5 \mathrm{~kW}$ PV system. This shows that the total capacity of PV installed is $39.5 \mathrm{~kW}$. Overall, $50.2 \%$ of the Respondents installed a $1.5 \mathrm{~kW}$ PV system, $24.2 \%$ installed a $1 \mathrm{~kW}$ PV system, $10 \%$ installed a $2 \mathrm{~kW}$ PV system, $8.7 \%$ installed a $2.5 \mathrm{~kW}$ PV system, $4.6 \%$ installed a $3.5 \mathrm{~kW}$ PV system, $1.4 \%$ installed a $4 \mathrm{~kW}$ PV system, and $0.5 \%$ installed a $3 \mathrm{~kW}$ and $5 \mathrm{~kW}$ PV system.

Table 4b: Status of Solar PV utilization for energy services in the study area

\begin{tabular}{lcccccccc}
\hline Characteristics & IHE & $\%$ & AHE & $\%$ & SHE & $\%$ & Total & $\%$ \\
\hline $\begin{array}{l}\text { Capacity of PV } \\
\text { installed }\end{array}$ & & & & & & & & \\
1 & 18 & 14.1 & 18 & 30.5 & 17 & 53.1 & 53 & 24.2 \\
1.5 & 67 & 52.3 & 28 & 47.5 & 15 & 46.9 & 110 & 50.2 \\
2 & 15 & 11.7 & 7 & 11.9 & 0 & 0 & 22 & 10.0 \\
2.5 & 17 & 13.3 & 2 & 3.4 & 0 & 0 & 19 & 8.7 \\
3 & 1 & .8 & 0 & 0 & 0 & 0 & 1 & .5
\end{tabular}

This shows that the total capacity of PV installed is $364.5 \mathrm{~kW}$. Table 4 also shows that in Ijapo Housing Estate (IHE), $58.6 \%$ of the respondent stated that their PV system is Working Very Well, 37.5\% stated that their PV system is working well, 3.1\% stated that their PV system is working moderately well, 0.8 stated that their PV system is not working well. In Alagbaka Housing Estate (AHE), 54.2\% of the respondent stated that their PV system is Working Very Well, $42.4 \%$ stated that their PV system is working well, 3.4\% stated that their PV system is working moderately well, none $(0 \%)$ stated that their PV system is not working well. In Sunshine Housing Estate (SHE), $87.5 \%$ of the respondent stated that their PV system is Working Very Well, 12.5\% stated that their PV system is working well, and none (0\%) stated that their PV system is working moderately well and not working well. Overall, 61.6 $\%$ of the respondent stated that their PV system is Working Very Well, 35.2\% stated that their PV system is working well, $2.7 \%$ stated that their PV system is working moderately well, 0.5 stated that their PV system is not working well. Table 4 also shows that in Ijapo Housing Estate (IHE), $62.5 \%$ of the respondent stated that they use their installed Solar PV for 5-6 hours per day, $25.8 \%$ stated that they use their installed Solar PV for 7-8 hours daily, and 9.4\% stated that they use their installed Solar PV for 3-4 hours daily. 1.6\% for 9-10 hours and $0.8 \%$ for $11-12$ hours. In Alagbaka Housing Estate (AHE), 81.4\% of the respondent stated that they use their installed Solar PV for 5-6 hours per day, $11.9 \%$ stated that they use their installed Solar PV for 3-4 hours daily, and 6.8\% stated that they use their installed Solar PV for 7-8 hours daily, and none (0\%) use it for 9-10 hours and 11-12 hours. In Sunshine Housing Estate (SHE), 96.9\% of the respondent stated that they use their installed Solar PV for 5-6 hours per day, 3.1\% stated that they use their installed Solar PV for 3-4 hours daily, and none (0\%) use it for 7-8 hours, 9-10 hours and $11-12$ hours. Overall, $72.6 \%$ of the respondent stated that they use their installed Solar PV for 5-6 hours per day, 16.9\% stated that they use their installed Solar PV for 7-8 hours 


\section{International Journal of Engineering Applied Sciences and Technology, 2020 Vol. 4, Issue 10, ISSN No. 2455-2143, Pages 386-394 \\ Published Online February 2020 in IJEAST (http://www.ijeast.com)}

daily, and $9.1 \%$ stated that they use their installed Solar PV for 3-4 hours daily.

\section{CONCLUSION}

The study assessed the current status of Solar Photovoltaic utilization for energy services in Akure. The study found that the current status of Solar PV utilization in the study area is still low despite various government interventions. The number of households Connected is 219 , which makes $20.2 \%$ of the households in the state. The most common application is solar home system installation with a Total capacity of $364.5 \mathrm{~kW}$ which were installed between 2011 and 2019. The installation comprises of Solar Panel, Storage Battery, Inverter, Charge controllers and ELCB Breaker. The PV Installation is used as an alternative Energy source. The PV installations are Self-sponsored, and $61.6 \%$ of the PV system is working very well and last an average of 6 hours. The users are responsible for monitoring and sustainability.

The results showed that the current contribution of solar PV in energy demand split for the estates was still meagre, with a total share of $7.3 \%$ despite various government interventions. Its usage level constituted an insignificant share of $27.2 \%, 59.6 \%, 16.3 \%, 0 \%, 0 \%, 0 \%, 0 \%$ and $6.9 \%$ for the total lighting, computing/internet, entertainment, process heat, cooking, refrigeration, water pumping and ventilation services requirement respectively.

Based on the findings from the study, the following are recommended

1. Government support for solar PV intervention in these Estates should be further encouraged.

2. Solar PV Usage for lighting, entertainment and computing services by the Estates is commendable and an increase in the intensity of usage essential.

3. Its usage for food and vaccine preservation through refrigeration; ventilation and water pumping for provision of potable water and farm irrigation should also be researched.

\section{REFERENCES}

[1] United Nation Development Programme-UNDP (2015). Sustainable Development Goals (SDGs). [Retrieved on March 11 , 2019] http://www.undp.org/content/undp/en/home/mdgoverview /post-2015-development-agenda.html\&nbsp

[2] Stevance A-S., Dave G., Måns N. and David McCollum. (2017). A Guide to SDG Interactions: From Science to Implementation'. International Council for Science (ICSU). Chapter on SDG 7 (p. 127-173) includes Linkages between SDG7 and other SDGs. https://www.icsu.org/cms/2017/05/SDGs-Guide-toInteractions.pdf.

[3] Bazilian M., Nussbaumer P., Eibs-Singer C., BrewHammond A, Modi V., Sovacool B., Ramana V. and Aqrawi P. K. (2012). Improving Access to Modern Energy Services: Insights from Case Studies. Electr. J., 25, pp 93-114

[4] Pachauri S., van Ruijven B. J., Nagai Y., Riahi K., van Vuuren D. P., Brew-Hammond A. and Nakicenovic N.
(2013). Pathways to achieve universal household access to modern energy by 2030. Environ. Res. Lett, 8, 24015, pp. 1-7. https://iopscience.iop.org/article/10.1088/17489326/8/2/024015/pdf

[5] Groh S. (2014). The role of energy in development processes - the energy poverty penalty: Case study of Arequipa (Peru). Energy for Sustainable Development. 18, pp. 83-99. https://doi.org/10.1016/j.esd.2013.12.002

[6] Ulsrud, K., Winther, T., Palit, D. and Rohracher, H. (2015): Village-level solar power in Africa: Accelerating access to electricity services through a socio-technical design in Kenya. Energy Res. Soc. Sci. 2015, 5, 34-44. https://doi.org/10.1016/j.erss.2014.12.009

[7] Akinwale Y, Ogundari I, Ilevbare O and Adepoju A. (2014): A Descriptive analysis of public understanding and attitudes of renewable energy resources towards energy access and development in Nigeria, International Journal of Energy Economics and Policy, 4 (4) pages 636-646.

http://www.econjournals.com/index.php/ijeep/article/view 1909

[8] Akinwale Y, Jesuleye A, and Siyanbola W. (2013): Empirical analysis of the causal relationship between electricity consumption and economic growth in Nigeria, British Journal of Economics, Management and Trade, 3 (3) pages 277-295. https://doi.org/10.9734/BJEMT/2013/4423

[9] Akinlo, A. (2009): Electricity consumption and economic growth in Nigeria: evidence from cointegration and cofeature analysis, Journal of Policy Modelling, 31 (5). pp. 681-693. https://doi.org/10.1016/j.jpolmod.2009.03.004

[10] Karekezi, S. and McDade W. (2011): Renewable energy strategies for rural Africa: Is a PV-led renewable energy strategy the right approaches for providing modern energy to the rural poor of sub-Saharan Africa. Energy Policy, 30, pp. 1071-86. https://doi.org/10.1016/S03014215(02)00059-9

[11] Kaygusuz, K. (2011): Energy services and energy poverty for sustainable rural development. Renewable and Sustainable Energy Reviews, 15, pp. 936-947. https://doi.org/10.1016/j.rser.2010.11.003

[12] Iwayemi, A. (2008): Nigeria's dual energy problems: Policy issues and challenges. International Association for energy economics, 53, pp. 17-21 www.iaee.org/en/publications/newsletterdl.aspx?id=53

[13] Akinboro, F, Adejumobi, L. A. and Makinde, V. (2012). Solar Energy Installation in Nigeria: Observations, Prospect, Problems, and Solution. Transnational Journal of Science and Technology, 2(4), 73-84. http://www.tjournal.org/tjst_may 2012/7.pdf?i=1

[14] Jesuleye, O.A. (2010): Analysis of Solar Photovoltaics Utilization in Selected Rural Areas of Nigeria, Ph.D. dissertation, Technology Planning and Development Unit, Obafemi Awolowo University, Ile-Ife.

[15] ECN \& UNDP. (2005): Nigeria Renewable Energy Master Plan (REMP); Retrieved March, 2019 www.areanet.org/fileadmin/user_uploada/AREA/AREA 


\section{International Journal of Engineering Applied Sciences and Technology, 2020 \\ Vol. 4, Issue 10, ISSN No. 2455-2143, Pages 386-394 \\ Published Online February 2020 in IJEAST (http://www.ijeast.com)}

downloads/AREA_Conferene_09/Presentations/Nigeria Renewable_Energy_Masterplan.pdf

[16] Hosenuzzaman, M. (2015): Global prospects, progress, policies, and environmental impact of solar photovoltaic power generation. Renewable Sustainable Energy Review, 41, 284-297. https://doi.org/10.1016/j.rser.2014.08.046

[17] Lan, Z. and Li, J. (2014): Photovoltaic technology and electricity saving strategies for fixedvelocity- measuring system. TELKOMNIKA Indones J Electr Eng, 12 (6) 4419-4426.

http://ijeecs.iaescore.com/index.php/IJEECS/article/view/ $\underline{3521 / 1786}$

[18] Silveira, J. L., Tuna, C. E. and Lamas, W. Q. (2013): The need of subsidy for the implementation of photovoltaic solar energy as supporting of decentralized electrical power generation in Brazil. Renewable Sustainable Energy Review, 20, 133-141. https://doi.org/10.1016/j.rser.2012.11.054

[19] REN21, (2018): Renewable global status report 2018 update. Renewable Energy Policy Network for the 21st century.

[20] Jesuleye, O.A. (2010): Solar PV demand for lighting in Nigerian remote villages International Journal of Management and Applied Science, ISSN: 2394-7926 Volume-3, Issue-10, Oct.-2017 http://iraj.in

[21] Ismail, O. S., Ajide, O. O., \& Akingbesote, F. (2012): Performance Assessment of Installed Solar PV System: A Case Study of Oke-Agunla in Nigeria. Engineering, 4(08), 453. https://doi:10.4236/eng.2012.48059

[22] Melodi, A. O. and Famakin, S. R. (2011): Assessment of Solar PV-Grid Parity Akure, South-West Nigeria. Journal of Emerging trend in Engineering and Applied Sciences $\begin{array}{lll}\text { JETAS, } & 2 & \text { (3), 531-536. }\end{array}$ http://jeteas.scholarlinkresearch.com/articles/Assessment $\% 20$ of $\% 20$ Solar\%20PvGrid\%20Parity\%20in\%20Akure,\%20SouthWest\%20Nigeria.pdf

[23] Cooper, D. R, \& Schindler, P.S (2003): Business Research Meethods. UK: Oxford University Press.

[24] Mugenda, O. M, \& Mugenda, A. G. (2003): Research Methods: Quantitative and Qualitative Approaches. Nairobi: African Centre for technology Studies

[25] Asiyanbola, R. A (2005): Patriarchy, Male Dominance, the Role and Women in Nigeria. Paper Submitted for presentation as poster at the international Union for scientific Study of population (IUSSP/UIESP) XXV International Population Tours, France, 18-23 https://www.semanticsscholar.org/paper/patriarchy-\%2Cmale-dominance-\%2C-the-role-and-women-inAsiyanbola/cca9d9aabdb150739fb73f8a22ae9f7392bd8eb I

[26] Olaniyan, K, Mclellan, B.,Ogata, S., \& Tezuka, T. (2018): Estimating Residential Energy Consumption in Nigeria to Support Energy Transitions. Sustainability. https://doi.org/10.3390/su10051440 Fakere, A. A (2017): Effects of Levels of Residents' Participation in House Design on Residential Satisfaction in Public Housing
Estates in Akure, Nigeria. Covenant Journal of Research in the Built Environment. 5 (1), pp. 82-98. https://journals.covenantuniversity.edu.ng/index.php/cjrbe /article/view/495 